\title{
Temperature-related phenotypic plasticity in the green microalga Micrasterias rotata
}

\author{
Jiří Neustupa*, Jan Št'astný, Ladislav Hodač \\ Department of Botany, Charles University of Prague, Benatska 2, Prague 2, 128 01, Czech Republic
}

\begin{abstract}
Temperature-related morphological variation of Micrasterias rotata (Desmidiales) strain CAUP K604 was investigated using landmark-based geometric morphometrics. Cultured morphotypes were compared with natural populations of $M$. rotata collected in different seasons at a central European lowland peat bog. In addition, we compared temperature-related variation with morphometric differentiation among other species within the genus Micrasterias. As temperatures increased, the population size of cultured $M$. rotata generally decreased and shape of the individual temperature groups differed significantly. The high temperature $\left(30^{\circ} \mathrm{C}\right)$ population contained the vegetative diploid cells. The shape variation related to temperature was similar to the size-related change in shape. Natural populations of $M$. rotata were consistently similar to the low temperature cultured populations throughout the season, while the high temperature morphotypes seen in culture were not present in natural samples.
\end{abstract}

KEY WORDS: Geometric morphometrics - Desmidiales · Phenotypic plasticity · Thin-plate spline

\section{INTRODUCTION}

A temperature-related decrease in the body size of protists has been demonstrated by several authors (Atkinson et al. 2003, De Boer et al. 2005, Gächter \& Weisse 2006). Atkinson et al. (2003) proposed a model, based on meta-analysis of literature data covering a wide range of aquatic protist organisms, indicating an approximately $2.5 \%$ reduction in cell size for each $1^{\circ} \mathrm{C}$ increase in temperature within a range that is normally encountered by an organism in nature. However, cell size usually increases in low sublethal temperatures and this partially hampers the population growth (Atkinson et al. 2003).

A temperature-related decrease in cell size was explained by either a higher fitness in populations that divide earlier as population growth rate increases in a higher temperature environment, or as an adaptation to facilitate the consumption of resources, whose availability is reduced by increased temperature (Atkinson et al. 2003). However, little data exist on temperaturerelated shape variation of eukaryotic microorganisms. Increased phenotypic plasticity has been correlated to environmental stress, and high temperatures can affect morphogenetic processes, leading to more variable or even teratogenic shapes of the high-temperature populations (Kristensen et al. 2003). In the present study temperature-related phenotypic plasticity of a freshwater unicellular green alga, Micrasterias rotata (Desmidiales, Viridiplantae), was investigated.

The complex morphology and relatively large size of Micrasterias cells have made members of this genus the favorite model organism for morphogenetic and plasticity studies (Kallio 1953, Meindl 1993, Weiss et al. 1999). As seen from the front, Micrasterias cells are composed of 2 flat symmetrical semicells that are bilaterally symmetrical (Fig. 1A). Each semicell consists of a central polar lobe and 2 lateral lobes that are further divided into individual lobules (Prescott et al. 1977). Meindl (1993) demonstrated that the bilateral symmetry of semicells and standard pattern of lobes and lobules is completely lost in Micrasterias denticulata cells grown at temperatures elevated to about $35^{\circ} \mathrm{C}$. Extensive morphological malformations also occurred in populations of the same species exposed to short-term approximately $40^{\circ} \mathrm{C}$ heat shocks (Weiss et al. 1999). 

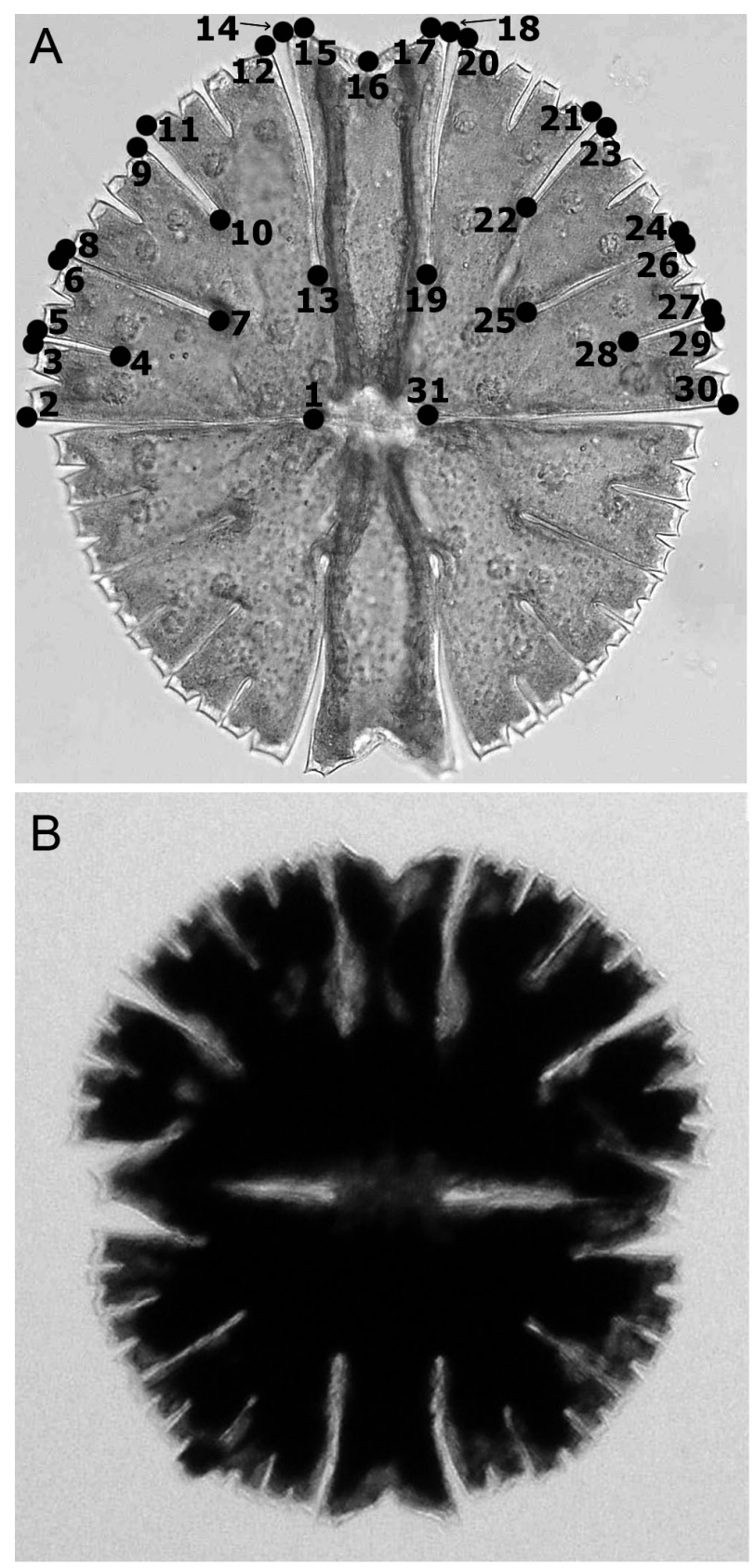

Fig. 1. Micrasterias rotata. Morphology of vegetative cells and positions of landmarks. (A) The standard haploid cell with positions of 31 landmarks (indicated by numbers) on the adult semicell. (B) The vegetative diploid cell from the $30^{\circ} \mathrm{C}$ population

However, the effect of higher temperatures on phenotypic plasticity at levels that would not completely disrupt the morphogenetic processes was not investigated.

Landmark-based geometric morphometrics (Bookstein 1991) can be used to precisely characterize patterns of morphological variation and quantify the plas- ticity levels using morphological disparity measures of individual species or populations (Zelditch et al. 2004). In contrast to conventional morphometric methods, geometric morphometric data are able to represent variation in shape as a whole in an investigated data set. The higher statistical power of geometric morphometric methods compared with traditional measurements to discriminate biological objects has been demonstrated many times in different organisms (e.g. Rohlf 2000, Monteiro et al. 2002), including microalgae (Beszteri et al. 2005). These methods have been used increasingly in algal and protist research in both taxonomic (Beszteri et al. 2005, Neustupa \& Němcová 2007) and ecological studies (Potapova \& Hamilton 2007). In desmids, correct infrageneric discrimination of populations belonging to 14 central European species of the genus Micrasterias was demonstrated by Neustupa \& Št'astný (2006) on the basis of geometric morphometric data. In addition, patterns of plasticity spanned by principal component analysis (PCA) of geometric morphometric data in 5 Micrasterias species populations were closely correlated with molecular phylogenetic data of the genus (Neustupa \& Škaloud 2007).

In the present study, species-specific variation in morphology relative to temperature level and the possible increase in phenotypic plasticity as a result of eventual stress-related morphogenetic disturbances in higher temperatures were investigated. In addition, using the comparative generic data set of Neustupa \& Št'astný (2006), the Micrasterias rotata data were compared with other species of the genus to illustrate infraspecific plasticity in relation to infrageneric differentiation. We asked whether the different experimental temperature conditions can shift resulting morphology so that the morphometric analysis would then not be able to unambiguously separate the $M$. rotata populations from other species of the genus. Finally, morphological variation in the cultured $M$. rotata strain with seasonal variation of natural populations of the same species was compared. We asked which temperature levels produced morphotypes most similar to those found in natural populations and whether the morphology of natural populations varied significantly during the season.

\section{MATERIALS AND METHODS}

The strain of Micrasterias rotata used in this study (CAUP K604) was originally obtained as a single cell isolate from benthos of flooded quarry pools near Cep village, South Bohemia, Czech Republic, in October 2005. Cultures were initiated with an inoculum of 15 cells and grown for $2 \mathrm{wk}$ in $250 \mathrm{ml}$ Erlenmeyer flasks 
containing liquid oligotrophic medium developed by the Culture Collection of Algae of Charles University of Prague (CAUP) (http://botany.natur.cuni.cz/algo/ caup.html). Cultures were maintained at temperatures of $10,15,20,25$ and $30^{\circ} \mathrm{C}$ and illuminated at $40 \mu \mathrm{mol}$ $\mathrm{m}^{-2} \mathrm{~s}^{-1}$ from $18 \mathrm{~W}$ cool fluorescent tubes (Philips TLD 18W/33), at a light:dark regime of 12:12 h. Micrographs were taken on an Olympus BX51 light microscope with Olympus Z5060 digital microphotographic equipment. As a comparative set of natural populations, 6 samples of phytobenthos dominated by Micrasterias rotata were collected from the benthos of a single 10 to $15 \mathrm{~cm}$ shallow peat bog pool in Borkovická Blata Nature Reserve in South Bohemia, Czech Republic, altitude $410 \mathrm{~m}$ above sea level (a.s.l.), pH 5.75 to 6.10. Samples were taken on 22 April, 19 May, 15 June, 26 July, 9 October and 7 December 2004.

For each temperature level and for each natural sample, 50 adult semicells were randomly chosen and photographed. On each semicell, 31 structurally corresponding landmarks were depicted (Fig. 1A, Table 1). For most of the geometric morphometric analyses the TPS-series software (Rohlf 2006) was used. Landmark positions, length and width of the cells and depth of the incisions were digitized in TpsDig, ver. 2.05. The incision depth was measured between landmark nos. 13 and 14 for the main incision between the polar and lateral lobes and between landmark nos. 6 and 7 for the incision between the lateral lobules. The landmark configurations were superimposed by generalized Procrustes analysis (GPA). This widely used method standardizes the size of the object and optimizes the rotation and translation so that the distances between corresponding landmarks of investigated objects are minimized (Bookstein 1991, Zelditch et al. 2004). The

Table 1. Micrasterias rotata. Position of landmarks for the geometric morphometric analysis as illustrated in Fig. 1A. Terminology follows Prescott et al. (1977)

\begin{tabular}{|ll|}
\hline Landmark nos. & Position \\
\hline 1,31 & Margins of isthmus \\
2,30 & Lower extremities of lower lateral lobules \\
3,29 & Upper extremities of 2nd order lower lateral lobules \\
4,28 & Bases of incisions in lower lateral lobules \\
5,27 & Lower extremities of 2nd order lower lateral lobules \\
6,26 & Upper extremities of lower lateral lobules \\
7,25 & Bases of incisions between lateral lobules \\
8,24 & Lower extremities of upper lateral lobules \\
9,23 & Upper extremities of 2nd order upper lateral lobules \\
10,22 & Bases of incisions of upper lateral lobules \\
11,21 & Lower extremities of 2nd order upper lateral lobules \\
12,20 & Upper extremities of upper lateral lobules \\
13,19 & Bases of incisions between polar and lateral lobes \\
14,18 & Lateral margins of the polar lobes \\
15,17 & Inner tooth of marginal extremities of the polar lobes \\
16 & Central incision of the polar lobe \\
\hline
\end{tabular}

TpsRelw, ver. 1.42, was used for GPA of our data set. Correlation between Procrustes and the Kendall tangent space distances was assessed using TpsSmall, ver. 1.20 , to ensure that the variation in shape was small enough to allow subsequent statistical analyses (Zelditch et al. 2004). The correlation of Procrustes and the Kendall shape spaces was very high ( $\mathrm{r}=0.999$ to 1.000 in all analysed data sets), so we proceeded with further analyses. As Micrasterias semicells are bilaterally symmetrical and anterior and posterior sides do not differ, cells were symmetrized prior to analysis following the standard formula of Klingenberg et al. (2002). This involved reflecting the cells (by multiplying the $x$-coordinates in all landmarks by -1$)$, then relabelling the paired landmarks in the reflected copy of landmark configurations and averaging the original and mirrored configurations in the Procrustes superimposition (GPA). The averages of original and reflected/relabelled cells are ideal symmetric shapes, where each half, together with landmarks lying on median axis, bears all the information on the shape of a symmetric object averaged from its halves. Consequently, further analyses were done using symmetrical configurations and the asymmetric component was omitted (Klingenberg et al. 2002). The PCA of geometric morphometric shape data was conducted on all cells grown at different temperature levels $\left(10\right.$ to $\left.30^{\circ} \mathrm{C}\right)$. Scores of the objects on the first 15 principal component (PC) axes (spanning $96.7 \%$ of the total variation) were used for canonical variate analysis (CVA) in PAST, ver 1.74 (Hammer et al. 2001), to test for and to visualize the differences between individual temperature levels. In addition, using scores on the first 15 PC axes the 2-group multivariate permutation tests (with 10000 permutations) on Mahalanobis distance between all pairs of temperature levels were conducted. The number of PC axes chosen was estimated so that all the axes with eigenvalues higher than the Jolliffe cut-off value (Jolliffe 1986) were included and they spanned at least $95 \%$ of the total variation to robustly represent variation in the original data set. Shape configurations typical for individual temperature levels were visualized as thin-plate splines of group centroids from the overall consensus configuration.

Multivariate regression of shape data on size was done in TpsRegr, ver. 1.31, using length, width and centroid size (CS) as measures of size in individual objects. This analysis was aimed to investigate the shape-to-size relationship representing the allomet- 
ric component of morphological variation. CS, the most common size measure in geometric morphometric studies (Zelditch et al. 2004), is defined as the square root of the sum of squared distances from the landmarks to their centroid (Bookstein 1991). In addition, multivariate regression of shape data on the temperature level was conducted. In both cases, significance of regression models was evaluated using permutation tests (with 1000 permutations) on Wilk's $\lambda$ and Goodall's F-ratio (Zelditch et al. 2004, Rohlf 2006). The significance of size differences between individual groups was assessed using permutation $t$-test (10000 permutations) on centroid sizes of individual objects in PAST, ver. 1.74. Morphological disparity of a population represents the quantitative measure of morphological variation. In geometric morphometric studies this morphological disparity is mostly used with the Procrustes distance as a measure of a distance in morphospace. In the present study, morphological disparity $(M)$ of populations cultured in individual temperature levels was evaluated using a formula with Procrustes shape data from superimpositions of individual groups (Zelditch et al. 2004):

$$
M=\frac{\sum_{i=1}^{N}\left(D_{i}^{2}\right)}{(N-1)}
$$

where $D_{i}$ is the Procrustes distance of an individual object (semicell) to a consensus (mean) shape and $N$ is the number of objects. The contribution of each object to the overall morphological disparity of the set can be expressed as partial morphological disparity index (PM):

$$
\mathrm{PM}=\frac{D_{i}^{2}}{N-1}
$$

The sum of PM values of all objects equals the value of morphological disparity index $M$ of a set as a whole. Differences in morphological disparity between individual groups were evaluated by a permutation test with 10000 permutations using partial morphological disparity PM based on Procrustes distances. For this permutation test the R 2.3.1. routine (R Core Development Team 2006) was used (Neustupa \& Němcová 2007).

The data set of 14 central European Micrasterias species of Neustupa \& Št'astný (2006) and 6 additional natural samples of $M$. rotata were used for morphological comparisons with cultured $M$. rotata shapes from different temperatures. In total, 17 structurally homologous landmarks that can be delimited in all species (Neustupa \& Št'astný 2006) were used. Thus, we compiled a data set consisting of $5 \mathrm{M}$. rotata mean configurations from different temperatures, $6 \mathrm{M}$. rotata mean configurations from natural samples taken at different dates and 13 configurations of other Micrasterias spe- cies. The PCA was done with this data set (using left halves of symmetric configurations, thus consisting of 9 landmarks) and the shape similarities of individual objects were illustrated by ordination diagrams. With scores from the first 12 PC axes (spanning $97.9 \%$ of the total variation), the Euclidean distances, based on the unweighted pair group method with arithmetic mean cluster analysis (UPGMA) of our data set, were then calculated and the resulting tree was bootstrapped using 10000 repetitions. For illustration of shape similarities in $M$. rotata populations and in 2 other most similar species ( $M$. papillifera and $M$. fimbriata), the principal coordinates analysis (PCoA) based on Euclidean distances was conducted on a limited dataset of 13 objects using scores on 12 PC axes. Ordination and cluster analyses were done in TpsRelw, ver. 1.42, and in PAST, ver. 1.74.

\section{RESULTS}

Micrasterias rotata strain CAUP K604 grew at temperatures of $10,15,20,25$ and $30^{\circ} \mathrm{C}$ and more than 500 cells were present after 2 wk of cultivation at all temperature levels. However, in the $30^{\circ} \mathrm{C}$ cultures $\sim 28 \%$ of cells were teratogenic vegetative diploids with multiple lateral lobules (Fig. 1B) as demonstrated by Kallio (1953). The morphology of these cells differed profoundly from the standard haploid morphotype of the species, and the landmarks in lower lateral lobules of diploid cells could not be homologized with the standard morphotype. Therefore, these cells were not analyzed and further analyses were conducted only on standard haploid vegetative cells with typical $M$. rotata morphology that includes 2 asymmetric lateral lobules (Fig. 1A).

The CVA revealed highly significant differentiation between cultured populations from individual temperatures (Wilk's $\lambda=0.0132, \mathrm{p}<0.0001$ ), with individual populations roughly grouped along the first CV axis (Fig. 2A). All group pairs significantly differed in shape with permutation $\mathrm{p}=0.0001$ in all 2 -group multivariate comparisons. Mean landmark configurations of populations from different temperatures are illustrated in Fig. 3. The low temperature cells were characterized primarily by protruding polar lobes and deep incisions between lobes and lobules. These features were most prominent in 10 and $15^{\circ} \mathrm{C}$ groups. The cells growing at $20^{\circ} \mathrm{C}$ and higher temperatures had other distinct shape characteristics. The polar lobes were flatter and did not protrude over adjacent lateral lobes. In addition, the incisions in semicells were about 15 to $20 \%$ shallower in highest levels than in the low temperature groups (Table 2) and their depth decreased gradually in relation to increasing temperature (Fig. 4A,B). The 


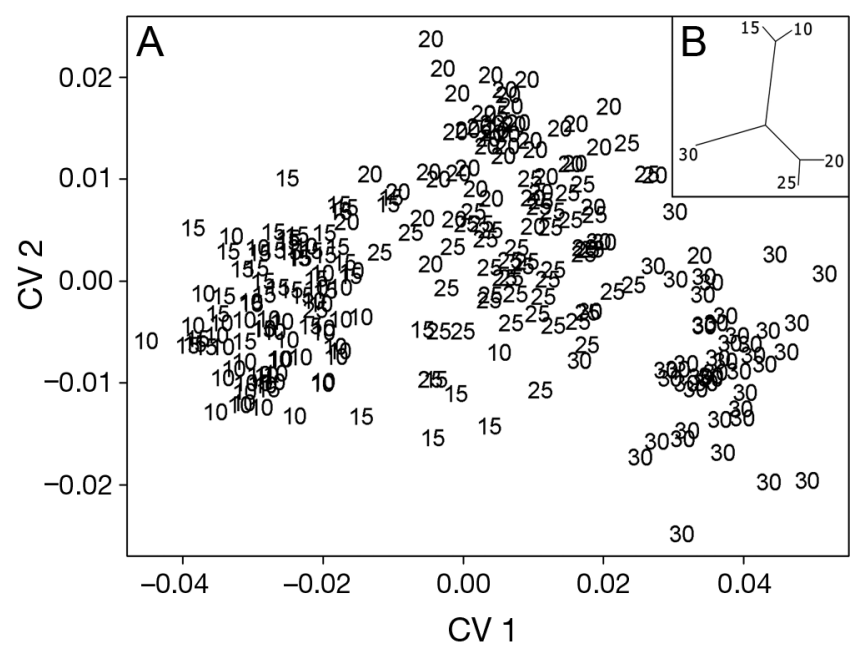

Fig. 2. Micrasterias rotata. Discrimination of shapes from different temperature levels. (A) The CVA ordination plot of shape data according to temperature groups $(\mathrm{CV}=$ canonical variate). Positions of individual cells are indicated by their temperature group (i.e. $10,15,20,25$ and $30^{\circ} \mathrm{C}$ ). (B) The UPGMA tree based on Procrustes distances of mean configurations of individual temperature groups

UPGMA tree of the matrix of Procrustes distances between consensus configurations of temperature groups demonstrated a pattern similar to the CVA ordination diagram (Fig. 2B). The low temperature 10 and $15^{\circ} \mathrm{C}$ groups clustered closely together. The groups from higher temperatures formed a loose cluster including the closely similar 20 and $25^{\circ} \mathrm{C}$ groups adjacent to the more distant $30^{\circ} \mathrm{C}$ group. The individual cell size measurements (length and width of the cells and the CS of landmark configurations) were tightly correlated ( $\mathrm{r}=0.94$ to $0.97, \mathrm{p}<0.0001)$ in all pairs. Therefore, further shape-to-size analyses were conducted using CS as a single measure. The populations of Micrasterias rotata from different temperatures differed in size that continually decreased at temperature-levels higher than $15^{\circ} \mathrm{C}$ (Fig. $4 \mathrm{C}-\mathrm{E}$ ). However, the $10^{\circ} \mathrm{C}$ population had significantly smaller cells than the $15^{\circ} \mathrm{C}$ group (permutation $\mathrm{p}=0.0119$ ). A decrease in size between individual temperature groups from $15^{\circ} \mathrm{C}$ was significant in all pairs with the permutation $\mathrm{p}=$ 0.0001 , except in 20 and $25^{\circ} \mathrm{C}$ pairs with $\mathrm{p}=0.0082$. The relation of shape data and CS was highly significant (Wilk's $\lambda=0.207$, permutation $\mathrm{p}=0.001$; Goodall's F-ratio $=148.7$, permutation $p=0.001,62.5 \%$ of variation unexplained by the regression model). Cell shape also differed significantly with temperature (Wilk's $\lambda=$ 0.106, permutation $\mathrm{p}=0.001$; Goodall's F-ratio $=163.1$, permutation $\mathrm{p}=0.001,60.4 \%$ of variation unexplained by the regression model). The shapes reconstructed by the multivariate regression models characteristic for highest temperature levels were markedly similar to those of smallest size values and vice versa (Fig. 5). The general shape trend was very similar to that visible in consensus configurations of temperature groups (Fig. 3). The shape-to-size regression trends within individual temperature groups and natural samples
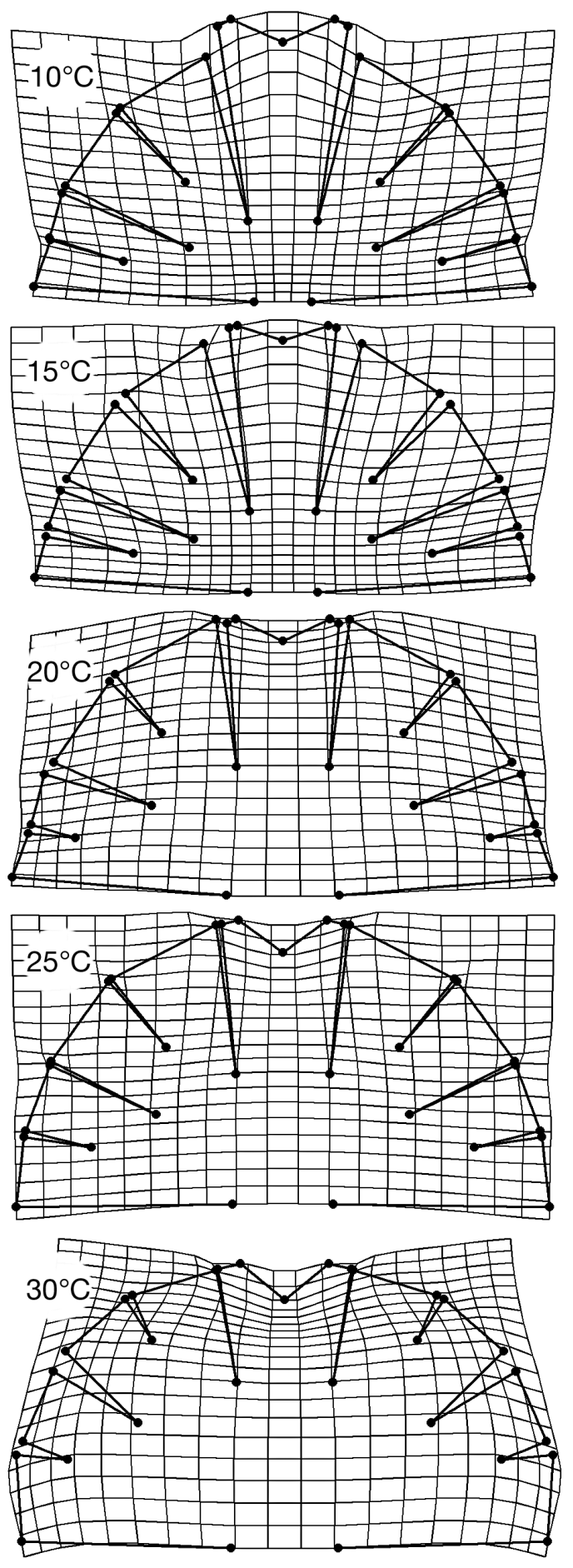

Fig. 3. Micrasterias rotata. The shapes of mean configurations of individual temperature groups illustrated by thin-plate splines from the overall consensus configuration 
Table 2. Micrasterias rotata. Size measurements of cells cultured at different temperature levels. $\mathrm{P} / \mathrm{L}=$ the incision between polar and lateral lobes, $\mathrm{L} / \mathrm{L}=$ the main incision between the pair of lateral lobules. Values are mean, with coefficient of variation in brackets

\begin{tabular}{|lccccc|}
\hline Temp. $\left({ }^{\circ} \mathrm{C}\right)$ & P/L $(\mu \mathrm{m})$ & L/L $(\mu \mathrm{m})$ & Length $(\mu \mathrm{m})$ & Width $(\mu \mathrm{m})$ & Centroid size \\
\hline 10 & $70.2(0.165)$ & $53.2(0.160)$ & $261.2(0.038)$ & $221.9(0.032)$ & $1023(0.034)$ \\
15 & $67.2(0.162)$ & $51.4(0.165)$ & $266.3(0.053)$ & $228.5(0.052)$ & $1046(0.048)$ \\
20 & $62.2(0.108)$ & $47.7(0.106)$ & $229.5(0.06)$ & $203.2(0.079)$ & $928(0.066)$ \\
25 & $60.9(0.106)$ & $46.8(0.103)$ & $225.9(0.036)$ & $197.6(0.039)$ & $914(0.042)$ \\
30 & $56.7(0.071)$ & $44.4(0.086)$ & $219.9(0.035)$ & $187.1(0.032)$ & $862(0.039)$ \\
\hline
\end{tabular}
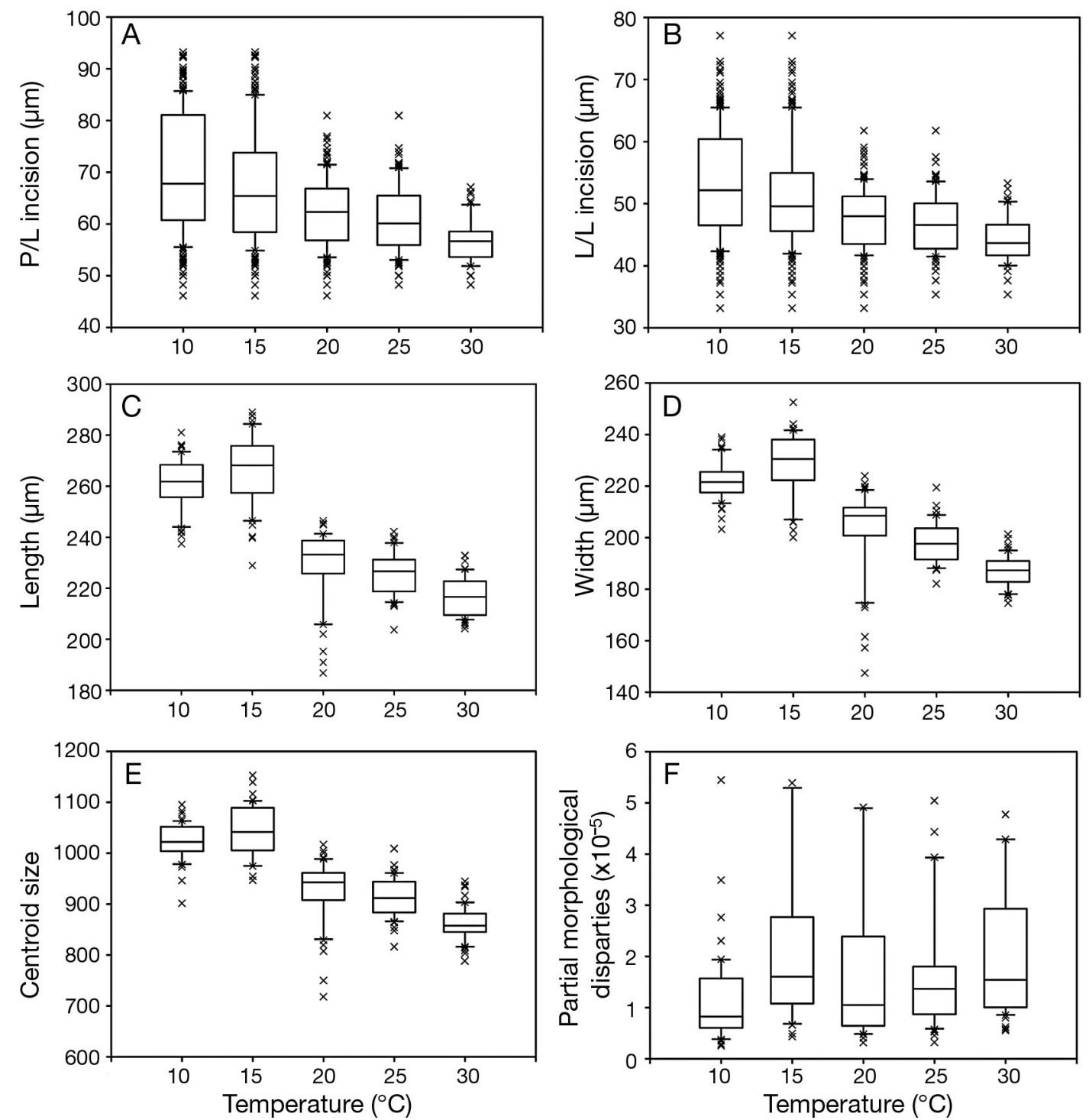

Fig. 4. Micrasterias rotata. Size and disparity measurements versus experimental temperature. (A) Depth of the incision between the polar and lateral lobes (P/L) in cells from different temperatures. (B) Depth of the incision between the 2 lateral lobules (L/L) in cells from different temperatures. (C) Length of the cells from individual temperature levels. (D) Width of the cells from individual temperature levels. (E) Centroid size of cells in different temperatures. (F) Partial morphological disparities indicating quantitative extent of morphological variation based on the common superimposition of cells from individual temperature groups. 

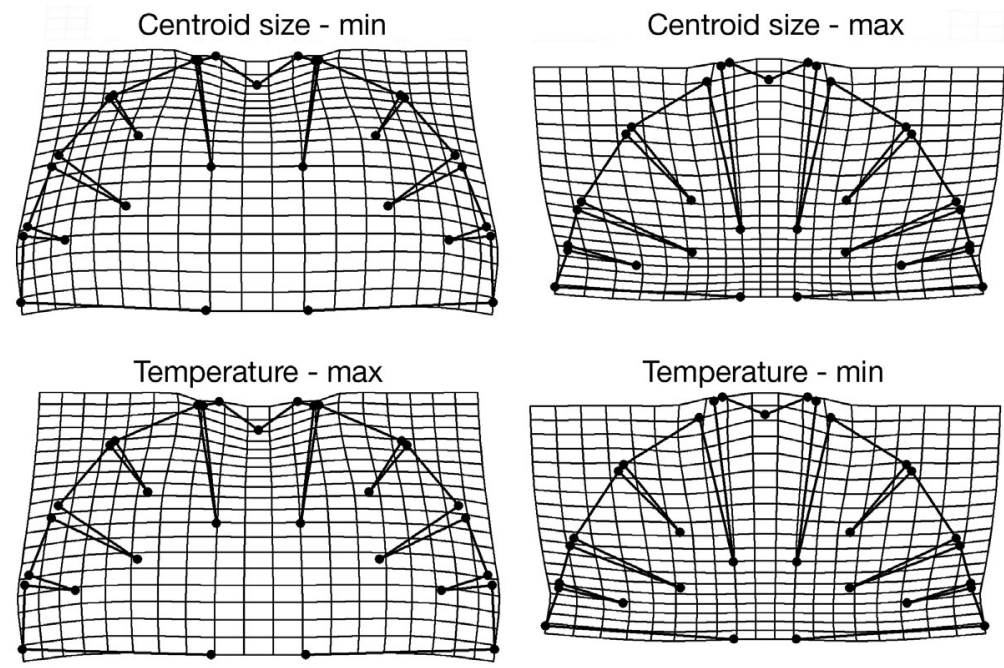

Fig. 5. Micrasterias rotata. Shapes of marginal configurations reconstructed by the regression models of shape data on size and on temperature

All of the Micrasterias rotata objects were tightly grouped together, but shapes of $M$. fimbriata and $M$. papillifera were also close to the $M$. rotata cluster in the ordination plot of first and second PC axes (PC1: $70.9 \%$, PC2: 13.6\%) from PCA of the combined data set of cultured $M$. rotata populations, natural populations of the same species and 13 other central European Micrasterias species (Fig. 6A). M. rotata objects had the lowest mutual Procrustes distances (i.e. were most similar to each other) in comparison with all the other species of the genus with the exception of the $30^{\circ} \mathrm{C}$ population whose shape was less similar to the natural samples and to the low temperature 10 and $15^{\circ} \mathrm{C}$ cultured populations of $M$. rotata than to shapes of $M$. papillifera and $M$. fimbriata. The UPGMA cluster dendrogram demonstrated a similar pat-

(not shown) consistently revealed the same and single morphological dynamics that were very similar to that of the complete data set. The smallest cells typically had deep incisions between lobes and lobules. Conversely, the largest cells generally had much shallower incisions within all temperature groups. All shape-tosize multivariate regressions in individual temperature groups were significant with permutation $\mathrm{p}=0.001$ for both Wilk's $\lambda$ and Goodall's F-ratio.

Tests on morphological disparities of different temperature sets revealed that the $10^{\circ} \mathrm{C}$ population was significantly less variable than all the other sets (permutation $\mathrm{p}=0.0002$ to 0.0115 ). The values of morphological disparity $(M)$ indicating the quantitative measure of plasticity in each population (Zelditch et al. 2004 ) were $5.8 \times 10^{-4}$ for the $10^{\circ} \mathrm{C}$ population and $9.5 \times$ $10^{-4}$ to $1.2 \times 10^{-3}$ in other temperature levels (Fig. 4F). Differences between populations from 15 to $30^{\circ} \mathrm{C}$ levels were not significant.

Fig. 6. Micrasterias spp. Ordination analyses of shape data of M. rotata populations combined with 13 other central European species illustrated by (A) the ordination plot of PCA involving all the investigated $M$. rotata cultured and natural populations and 13 other Micrasterias species (RW = relative warp), and (B) the ordination plot of PCoA of a data set comprising the $M$. rotata populations and 2 other most similar species $(\mathrm{PCo}=$ principal coordinate). $\mathrm{AM}=$ Micrasterias americana, $\mathrm{AP}=M$. apiculata, $\mathrm{BR}=M$. brachyptera, $\mathrm{CM}=M$. crux-melitensis, $\mathrm{DC}=M$. decemdentata, $\mathrm{DE}=M$. denticulata, $\mathrm{FI}=M$. fimbriata, $\mathrm{FU}=M$. furcata, $\mathrm{JE}=M$. jenneri, $\mathrm{PA}=M$. papillifera, $\mathrm{RA}=M$. radiosa, $\mathrm{RO}=M$. rotata, $\mathrm{TH}=M$. thomasiana, $\mathrm{TR}=M$. truncata. Months associated with RO indicate natural population samples; numbers associated with $\mathrm{RO}$ represent culture temperatures; the 10 and $15^{\circ} \mathrm{C} \mathrm{M}$. rotata populations are nested inside the natural samples tern (Fig. 7) and all the natural samples of $M$. rotata grouped together with 10 and $15^{\circ} \mathrm{C}$ cultured populations, whereas cells grown at higher temperatures
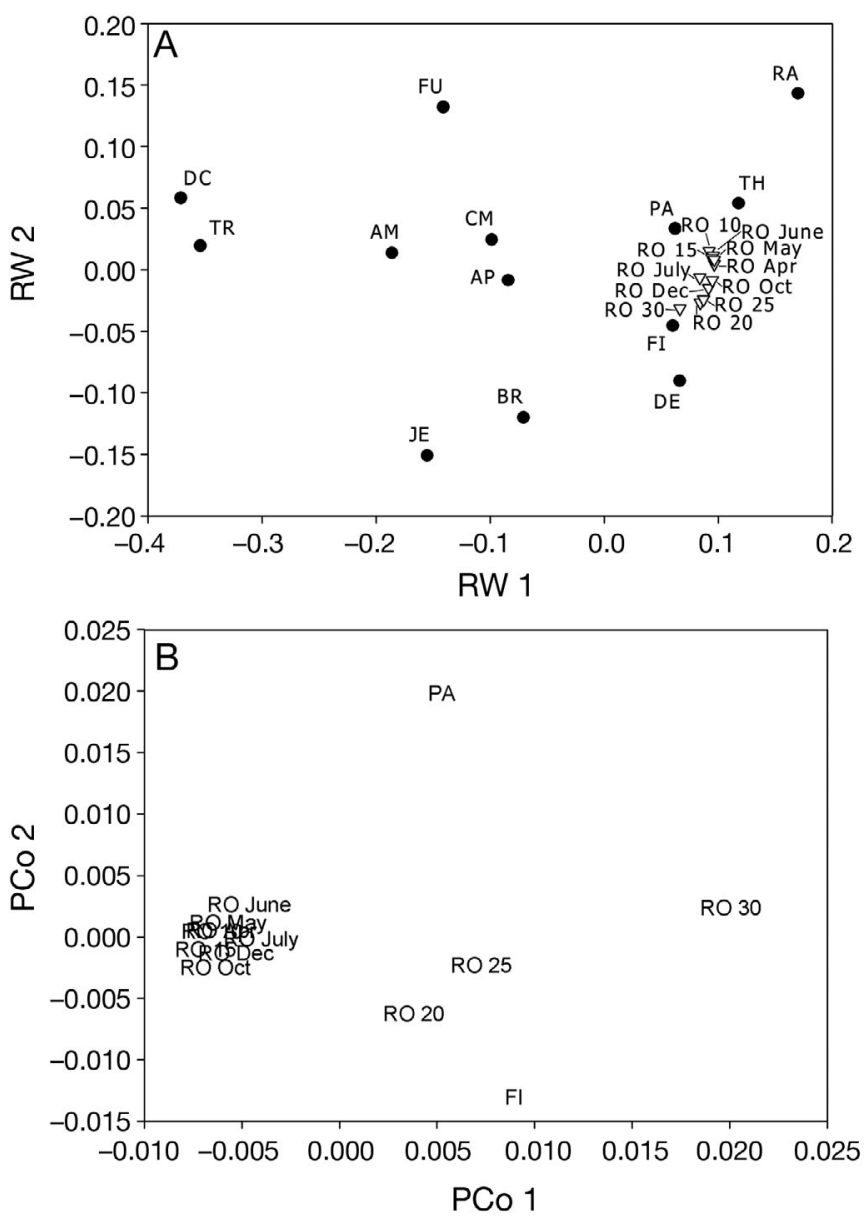


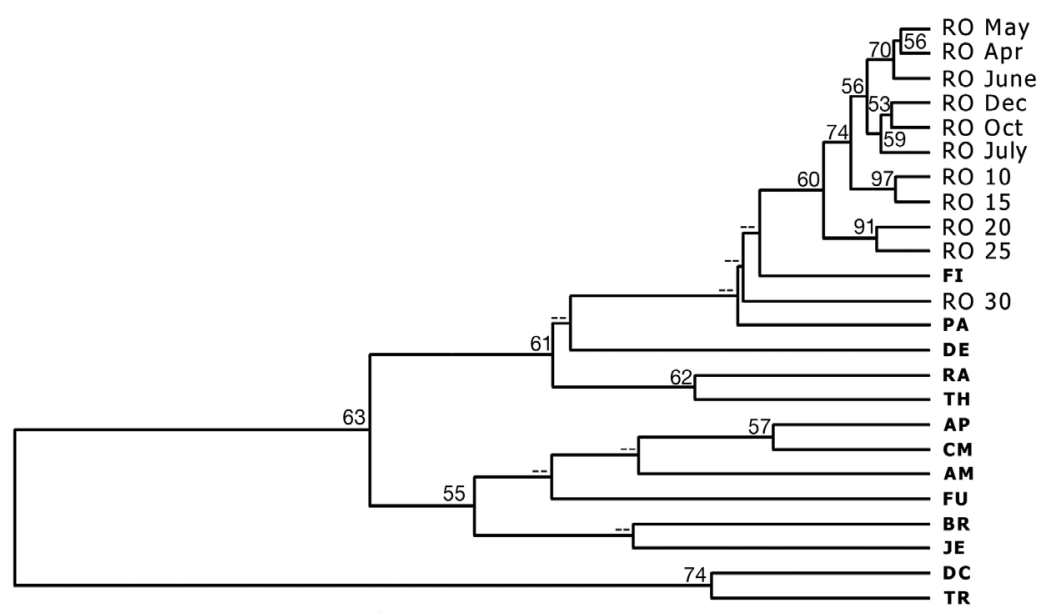

Fig. 7. Micrasterias spp. UPGMA tree of shape data of $M$. rotata populations and 13 other Micrasterias species. --: bootstrap values lower than $50 \%$. Sample designations are as defined for Fig. 6

were less similar to the natural samples. In the ordination diagram of the first 2 axes of PCoA that spanned $74.1 \%$ of the total variation (PCo1: $42.4 \%$, PCo2: $31.7 \%$ ) a tight cluster of natural samples together with cultured 10 and $15^{\circ} \mathrm{C}$ populations is evident (Fig. 6B).

\section{DISCUSSION}

Similar to other protists, the size of Micrasterias rotata cells cultured at different temperatures decreased consistently from 15 to $30^{\circ} \mathrm{C}$. However, the $10^{\circ} \mathrm{C}$ temperature group had significantly larger cells than the $15^{\circ} \mathrm{C}$ group, which corresponded with Atkinson et al. (2003), who proposed that cell size increases at very low temperatures below the range where the temperature-related size reduction rule applies. By accepting this model, we would have to admit that constant temperatures of about $10^{\circ} \mathrm{C}$ are below this limit in the investigated M. rotata strain. Cells cultured at $10^{\circ} \mathrm{C}$ also were less variable in cell shape than the other temperature groups as demonstrated by their significantly lower morphological disparity. This quantitative feature indicating the extent of plasticity did not differ in the $15^{\circ} \mathrm{C}$ and $30^{\circ} \mathrm{C}$ temperature groups, but the $30^{\circ} \mathrm{C}$ group contained about $28 \%$ of teratogenic vegetative diploid cells with multipled lateral lobules. Kallio (1953) reported 2 profoundly different experimental mechanisms that lead to development of vegetative diploids in Micrasterias - centrifugation and the shortterm cold shocks. The long-term cultivation at $30^{\circ} \mathrm{C}$ evidently leads to similar disruption of mitotic process in haploid vegetative cells. Presence of these teratogenic cells at $30^{\circ} \mathrm{C}$ could, thus, be interpreted as an indicator of stressing conditions that lead to disrup- tions in ontogenesis of semicells. Shapes of all temperature groups differed significantly, but the cells cultured at 10 and $15^{\circ} \mathrm{C}$ clustered close to each other, as did those cultured at 20 and $25^{\circ} \mathrm{C}$, whereas $30^{\circ} \mathrm{C}$ cells were more distant. Thus, the high temperature group cultured at $30^{\circ} \mathrm{C}$ was most dissimilar from all other groups, even when only the standard haploid vegetative cells were taken into account in the morphometric analysis. Both temperature and size explained similar patterns of shape change in the investigated data set. This phenomenon is not surprising given the fact that CS and temperature were closely and negatively correlated as a result of the 'temperature-size rule' (Atkinson 1994, Atkinson et al. 2003). The high temperature morphotypes were distinctly smaller and their morphology with shallower incisions was generally less elaborate than in low temperature cells. In addition, this pattern of size to shape relation was significant in all the temperature groups and natural samples. The plasticity trend of the incisions becoming shallower in $M$. rotata cells with decreasing cell size can, thus, probably be considered as a general feature of size-to-shape dynamics in this species. This morphological trend should be related primarily with size change as almost identical size-related morphological changes were observed within the individual temperature groups. Different temperature results in the size differences between populations and these, consequently, drive their morphological differentiation.

Two explanations were suggested for temperaturesize rule in protists (Atkinson et al. 2003). The surface:volume $(\mathrm{S}: \mathrm{V})$ ratio of cells increases with their decreasing size. The consumption of resources (carbon dioxide, nutrients) is known to be reduced at higher temperatures and an increase in the $\mathrm{S}: \mathrm{V}$ ratio by decreasing the cell size can then be considered an adaptive response (Margalef 1954, Spijkerman \& Coesel 1998, Cornet-Barthaux et al. 2007). The second hypothesis, however, presumes that population growth usually increases in protist populations as a consequence of a higher temperature that lies within the range of normally encountered values (Atkinson 1994, Atkinson et al. 2003). Selection pressure for earlier reproduction - one that is facilitated by earlier completion of the cell cycle and results in the smaller size of adult cells - is higher in rapidly growing populations because the offspring of smaller maternal cells then would constitute a larger fraction of the total population. This model is applicable especially in populations with low densities and, consequently, with abun- 
dant resources (Atkinson et al. 2003). Thus, a decrease in size related to temperature may be a result of plastic adaptive response connected with increased population growth.

Densities of our investigated populations were low, and the distinct size decrease with increasing temperature could correspond instead to the temperaturerelated faster cell cycle completion model. Moreover, the higher $\mathrm{S}: \mathrm{V}$ ratio of smaller cells is compensated by their shallower incisions (Figs. 3 \& 5) and this trend acts against increasing the $\mathrm{S}: \mathrm{V}$ ratio, which would eventually have to facilitate better consumption of resources according to the first hypothesis. Accelerated reproduction driven by smaller cell sizes correlates with their less elaborate shape. These morphological characteristics are probably a result of faster morphogenetic processes that lead to generally less accented shape features. Thus, our data better correspond to the hypothesis presuming plastic response to selection pressure for earlier reproduction in higher temperatures. However, this hypothesis could only be evaluated using growth rate data of populations from individual temperature levels. The positive correlation of the growth rate, temperature and, consequently, size of the cells would decisively support the idea that the faster cell cycle completion model provides a plausible explanation of temperature-related plasticity in Micrasterias.

The infraspecific shape differences were small in relation to interspecific differences within the genus as a whole (Fig. 6A). However, the consensual shapes of individual temperature groups did not form a clearly separated cluster from all the other species as they were intertwined with Micrasterias papillifera and $M$. fimbriata. Both of these species belong to a single clade together with $M$. rotata in molecular phylogenetic trees, and $M$. fimbriata is the species most closely related to $M$. rotata on the basis of molecular data (Neustupa \& Škaloud 2007). The $30^{\circ} \mathrm{C}$ population was even more similar to $M$. papillifera and $M$. fimbriata than to the low temperature and natural $M$. rotata sets which, again, illustrates its deviation from standard morphological patterns of the species. All of the natural $M$. rotata samples that were collected from April to December were closely similar to shapes of low temperature 10 and $15^{\circ} \mathrm{C}$ cultured populations (Figs. 6B \& 7 ). Even if the maximum daily temperatures reached at least $25^{\circ} \mathrm{C}$ in $40 \mathrm{~d}$ during the summer season of 2004 , the average temperature of the warmest month was $17.3^{\circ} \mathrm{C}$ and the lowest daily temperatures were never higher than $16^{\circ} \mathrm{C}$ in the Tábor station, which is the closest weather station to the sampling locality $(15 \mathrm{~km}$ and altitude $430 \mathrm{~m}$ a.s.l. [Czech Hydrometeorological Institute 2007]). Thus, temperature-related morphological variation in natural populations reflected the aver- age and lowest night air temperatures instead of the maximum daily levels. Desmids reproduce primarily during dark periods by dividing the vegetative cells in the isthmus plane (Brandham \& Godward 1965). We propose that night and early morning temperatures of a shallow pool correlating with air temperature fluctuations (Jacobs et al. 1997) are probably most related to size and shape properties of cells as they directly influence the morphogenetic processes following the vegetative cells division. Primary wall formation that precedes deposition of a rigid cellulose secondary wall lasts about 4 to $5 \mathrm{~h}$ in Micrasterias (Meindl 1993). This period probably is crucial for morphological characteristics of a developing semicell. Resulting morphology then reflects primarily the actual environmental conditions of the coldest day period, and the daily maximum temperatures reaching up to $30^{\circ} \mathrm{C}$ in June to August did not influence the morphological characteristics of investigated natural populations, whose shapes were consistently close to those of low temperature shapes of the 10 and $15^{\circ} \mathrm{C}$ cultured populations (Fig. 6B). This assumption could be evaluated further in experimental populations cultured in controlled fluctuating temperatures and is a challenge for future research.

Micrasterias rotata is a widely distributed freshwater species and has been reported also from tropical wetland habitats (e.g. Krieger 1939, Prescott 1951) where year-long average water temperatures are about $25^{\circ} \mathrm{C}$. The morphometric patterns of populations from such habitats would especially be of interest for a comparison with patterns of cultured high temperature populations. Eventual shape similarity of natural high temperature populations that grow in nutrient-limited and species-rich benthic tropical communities with the high temperature cultured populations would support the hypothesis of universal relevance of temperature levels in patterns of morphological differentiation of this species.

Acknowledgements. This study was supported by grant no. 206/05/P139 of the Czech Science Foundation and by the research project of the Czech Ministry of Education no. 0021620828. We thank the anonymous reviewers for their recommendations that led us to the improvements of the manuscript.

\section{LITERATURE CITED}

Atkinson D (1994) Temperature and organism size - a biological law for ectotherms? Adv Ecol Res 25:1-58

Atkinson D, Ciotti BJ, Montagnes DJS (2003) Protists decrease in size linearly with temperature: ca. $2.5 \%{ }^{\circ} \mathrm{C}^{-1}$. Proc R Soc Lond B Biol Sci 270:2605-2611

Beszteri B, Ács E, Medlin L (2005) Conventional and geometric morphometric studies of valve ultrastructural variation in two closely related Cyclotella species (Bacillariophyta). Eur J Phycol 40:89-103

Bookstein FL (1991) Morphometric tools for landmark data: 
geometry and biology. Cambridge University Press, Cambridge

Brandham PE, Godward MBE (1965) Mitotic peaks and mitotic time in the Desmidiaceae. Arch Microbiol 51: 393-398

Cornet-Barthaux V, Armand L, Quéguiner B (2007) Biovolume and biomass estimates of key diatoms in the Southern Ocean. Aquat Microb Ecol 48:295-308

Czech Hydrometeorological Institute (2007) Climate atlas of Czechia. CHMI, Prague

De Boer MK, Koolmees EM, Vrieling EG, Breeman AM, Van Russel M (2005) Temperature responses of three Fibrocapsa japonica strains (Raphidophyceae) from different climate regions. J Plankton Res 27:47-60

Gächter E, Weisse T (2006) Local adaptation among geographically distant clones of the cosmopolitan freshwater ciliate Meseres corlissi. I. Temperature response. Aquat Microb Ecol 45:291-300

Hammer Ø, Harper DAT, Ryan PD (2001) PAST: paleontological statistics software package for education and data analysis. Palaeont Electr 4:1-9

Jacobs AFG, Jetten TH, Lucassen DC, Heusinkveld BG, Nieveen JP (1997) Diurnal temperature fluctuations in a natural shallow water body. Agric For Meteorol 88: 269-277

Jolliffe IT (1986) Principal component analysis. Springer, New York

Kallio P (1953) On the morphogenetics of the desmids. Bull Torrey Bot Club 80:247-263

Klingenberg CP, Barluenga M, Meyer A (2002) Shape analysis of symmetric structures: quantifying variation among individuals and asymmetry. Evolution 56:1909-1920

Krieger W (1939) Die Desmidiaceen Europas mit Berücksichtigung der aussereuropäischen Arten. Dr. L. Rabenhorst's Kryptogamen-Flora von Deutschland, Österreich und der Schweiz. Band 13, Abteilung 1, Teil 2, Lieferung 1. Akademische Verlagsgesellschaft $\mathrm{MBH}$, Leipzig

Kristensen TN, Pertoldi C, Andersen DH, Loeschcke V (2003) The use of fluctuating asymmetry and phenotypic variability as indicators of developmental instability: a test of a new method employing clonal organisms and high temperature stress. Evol Ecol Res 5:53-68

Margalef R (1954) Modifications induced by different temperatures on the cells of Scenedesmus obliquus (Chlorophyceae). Hydrobiologia 6:83-94

Editorial responsibility: Patricia Glibert, Cambridge, Maryland, USA
Meindl U (1993) Micrasterias cells as a model system for research on morphogenesis. Microbiol Rev 57:415-433

Monteiro LR, Diniz JAF, dos Reis SF, Araujo ED (2002) Geometric estimates of heritability in biological shape. Evolution 56:563-572

Neustupa J, Němcová Y (2007) A geometric morphometric study of the variation in scales of Mallomonas striata (Synurophyceae, Heterokontophyta). Phycologia 46: 123-130

Neustupa J, Škaloud P (2007) Geometric morphometrics and qualitative patterns in the morphological variation of five species of Micrasterias (Zygnemophyceae, Viridiplantae). Preslia 79:401-417

Neustupa J, Št'astný J (2006) The geometric morphometric study of Central European species of the genus Micrasterias (Zygnematophyceae, Viridiplantae). Preslia 78: 253-263

Potapova M, Hamilton PB (2007) Morphological and ecological variation within the Achnanthidium minutissimum (Bacillariophyceae) species complex. J Phycol 43:561-575

Prescott GW (1951) Ecology of Panama Canal algae. Trans Am Microsc Soc 70:1-24

Prescott GW, Croasdale HT, Vinyard WC (1977) A synopsis of North American desmids, Part II. Desmidiaceae: Placodermae, Section 2. Univ Nebraska Press, Lincoln, NE

R Core Development Team (2006) R: a language and environment for statistical computing. R Foundation for Statistical Computing, Vienna

Rohlf FJ (2000) Statistical power comparisons among alternative morphometric methods. Am J Phys Anthropol 111: $463-478$

Rohlf FJ (2006) Tps series. Department of Ecology and Evolution, State University of New York at Stony Brook, New York

Spijkerman E, Coesel PFM (1998) Ecophysiological characteristics of two planktonic desmid species originating from trophically different lakes. Hydrobiologia 369/370: 109-116

Weiss D, Lütz C, Lütz-Meindl U (1999) Photosynthesis and heat response of the green alga Micrasterias denticulata (Desmidiaceae). Z Naturforsch 54C:508-516

Zelditch ML, Swiderski DL, Sheets DH, Fink WL (2004) Geometric morphometrics for biologists: a primer. Elsevier Academic Press, London

Submitted: November 12, 2007; Accepted: February 8, 2008 Proofs received from author(s): April 1, 2008 